\title{
The Biodiversity of Edible Flowers: Discovering New Tastes and New Health Benefits
}

\author{
Stefano Benvenuti* and Marco Mazzoncini \\ Department of Agricultural, Food and Agro-Environmental Sciences, University of Pisa, Pisa, Italy
}

\section{OPEN ACCESS}

Edited by: Antonio Ferrante,

University of Milan, Italy

Reviewed by:

Barbara De Lucia,

University of Bari Aldo Moro, Italy

Luana Fernandes,

Polytechnic Institute of Bragança

(IPB), Portugal

*Correspondence:

Stefano Benvenuti

stefano.benvenuti@unipi.it

Specialty section:

This article was submitted to Crop and Product Physiology,

a section of the journal

Frontiers in Plant Science

Received: 04 June 2020

Accepted: 28 October 2020

Published: 22 February 2021

Citation:

Benvenuti S and Mazzoncini M (2021) The Biodiversity of Edible Flowers: Discovering New Tastes

and New Health Benefits.

Front. Plant Sci. 11:569499.

doi: 10.3389/fp/s.2020.569499
Floriculture and horticulture have always been two parallel and very distinct agronomic realities. Floriculture is concerned with meeting the ornamental needs of our urban ecosystems, while horticulture is based on meeting food requirements. These two activities have now converged toward a food chain where flowers are conceived of as a sort of "new vegetable" and one of the most promising novelties to satisfy the growing need for food innovation both in terms of an organoleptic and nutraceutical profile. This novelty has rapidly evolved, especially following the growing scientific evidence of the human health benefits of flowers used as food. The typically high pigment concentration of the corollas (especially flavonoids and carotenoids), which have evolved to chromatically attract pollinators, indicates a marked nutraceutical activity especially in terms of antioxidant power. In this review, we first attempted to explore which species are most promising and which should be avoided due to real or suspected toxicity problems. The nutraceutical virtues were therefore highlighted trying to focus attention on those "functional phytochemicals" capable of counteracting some specific human pathologies. Furthermore, the organoleptic profile of edible flowers was investigated since this is one of the least known aspects. The cropping systems suitable for their cultivation were therefore hypothesized and finally the criticalities of edible flowers were addressed in terms of shelf life and marketing opportunities.

Keywords: ethnobotany, food safety, organoleptic perception, nutraceuticals, new foods

\section{INTRODUCTION}

The use of flowers as food is not, however, a new discovery, but a rediscovery of ancient ethnobotanical traditions. In fact, the Greeks and Romans used flowers both to give a surprising ornamental impact to various dishes (for example, rose petals in ancient Rome Melillo, 1994) and to enhance the organoleptic synergy between the taste of traditional foods (vegetables, meat, fish, etc.) and that of flower aromas. However, the gastronomic use of flowers has been limited to and dependent on the relatively narrow, seasonal timeframe in which these flowers proliferate almost exclusively in natural ecosystems. The use of mallow (Malva sylvestris), borage (Borago officinalis), and acacia (Robinia pseudoacacia) flowers are the best known examples of an appreciated but "season-dependent" food potential of flowers. Today this problem of seasonality has been gradually attenuated by an "agronomic conversion" of flower species that were traditionally cropped 
exclusively as ornamentals toward their cultivation for food purposes. Since this innovative agronomic chain intended for human consumption is recent, it is often not clear which species are actually edible and which are potentially toxic or even poisonous. The benefits, contraindications and potential toxicity of the biodiversity of wild flowers need to be clarified and so that there can be a focus on those suitable for food.

The growing interest in edible flowers is motivated not only by decorative and nutraceutical objectives, but also by the desire for new flavors and new opportunities for gastronomic innovation. The considerable nutraceutical activity in terms of antioxidant power of flowers (Falla et al., 2020; Mikołajczak et al., 2020) derives from their richness in generic phenolic compounds. flavonoids, consisting of flavonols, flavones, and anthocyanins show a strong biological activity. These chemicals play a crucial role in mitigating the oxidative stress induced by various pathologies. flowers are particularly rich in these phytochemicals. Almost all ornamental flowers have evolved chromatically showy corollas as a strategy to attract pollinators [mainly bees, solitary bees, bumblebees, hoverfly (Diptera Syrphidae), bee fly (Diptera Bombyliidae), and butterfly], since they are responsible for the gene flow within each species. The high pigmentation of the flower corollas derives from a coevolution mechanism with a mutual reward: (i) advertising for pollinators by increasing the degree of seed set and (ii) evolution of the visual system of pollinators thus facilitating the food detection (pollen and / or nectar). This also happens in intensely colored fruits (blackberries, blueberries, raspberries, etc.) in which the pigmentation derives from a flora-fauna co-evolution that facilitates fruit recognition and attractiveness thus leading to frugivorous dispersal. The heterogeneity of the botanical structures of several species of flowers is closely connected with their respective chemical diversity.

The aim of this review was to analyze the "state of the art" of edible flowers in terms of a botanical, phytochemical, nutraceutical, organoleptic, ecological and agronomic profile, as well as to verify their future perspectives in relation to consumer tastes and marketing.

\section{FLOWERS AS NUTRACEUTICAL FOOD}

The analysis of nutraceutical food has increasingly shown that in flower tissues there are a wide range of phytochemicals with positive effects on human health (Table 1). The most wellknown parameter of edible flowers is the marked antioxidant activity which is characteristic of almost all the species studied (Kaisoon et al., 2011; González-Barrio et al., 2018; KalembaDrożdż and Cierniak, 2019). A high antioxidant activity has been found not only in the floral tissues before their ingestion but also after the digestive processes, highlighting the prolonged bioactive effect of the various phytochemicals (Chen et al., 2015). This antioxidant activity involves the slowing down of cellular aging (Chen et al., 2020), and thus prevent and/or inhibit many pathologies (Lu et al., 2016).

In parallel with this widespread nutraceutical property, phytochemical and pharmaceutical experiments have shown that the flowers have a wide range of medicinal properties against specific pathologies (Figure 1). For example, it has been scientifically proven (Ukiya et al., 2002) that chrysanthemum flowers (Chrysanthemum morifolium) and other ornamental species (Pires et al., 2018) have anticancer properties. Similar nutraceutical activities have been demonstrated in a wide range of species that are "functional" to particular pathologies such as hypoglycemic (Loizzo et al., 2016), antimicrobial (Ksouri et al., 2009; Fernandes et al., 2017), anti-Alzheimer (Rezende et al., 2019), the prevention of liver injury (Sugawara and Igarashi, 2009), analgesic (Loganayaki et al., 2012), anti-obesity (Kim et al., 2017), visual health (Nwachukwu et al., 2016), neuroprotective (Ma and Wako, 2017), anti-bacterial (Pires et al., 2018), anti-obesity (Kim et al., 2017), and diuretic properties (Ratnasooriya et al., 2004). They can also help combat cardiovascular diseases (Koch and Malek, 2011). Flowers thus offer a wide range of phytochemical benefits to human health. Integrating them into a daily or periodic diet can help prevent generalized (i.e., antioxidant activity) and/or specific pathologies (Gostin and Waisundara, 2019).

\section{FLOWER CHEMICALS RESPONSIBLE FOR THE NUTRACEUTICAL ACTIVITY}

The considerable nutraceutical activity in terms of antioxidant power of flowers derives from their richness in generic phenolic compounds (Xiong et al., 2014). This biological activity (Ryu et al., 1994) is proportional to the content in carotenoids, flavonoids (especially anthocyanins), simple phenolic acids and also to vitamins and essential oils (Mlcek and Rop, 2011). From this wide range of phytochemicals, flavonoids, consisting of flavonols, flavones, and anthocyanins show a strong biological activity (Lu et al., 2016). These chemicals play a crucial role in mitigating the oxidative stress induced by various pathologies (Ishige et al., 2001). In relation to this, anthocyanins are particularly important since highly pigmented flowers have a high antioxidant activity (Khoo et al., 2017) compared to cultivars of the same species characterized by less pigmented flowers.

It is no coincidence that the flowers are particularly rich in these phytochemicals since the name anthocyanins derives from the ancient Greek "anthos" (=flower) and "kyáneos" (=blue). These water-soluble substances confer the characteristic red, purple or blue colors according to the $\mathrm{pH}$ and their structural features (Fossen and Andersen, 2003). Foods rich in these phytochemicals, especially flowers and fruits, are substances now considered as a real "pharmaceutical ingredients" with great benefits for human health (Khoo et al., 2017). Other pigments of crucial nutraceutical importance belong to the category of carotenoids which bestow yellow and orange colors. Flowers with these colors, such as the different species belonging to the botanical genus Tagetes, are particularly rich in violaxanthins, luteins, zeaxanthins, $\alpha$-carotenes, and $\beta$-carotenes (Park et al., 2017).

Among carotenes, the lutein concentration (Niizu and Rodriguez-Amaya, 2005) has active therapeutic benefits, particularly for the human eye. Very lutein-rich flowers are 
TABLE 1 | Biodiversity of flower species studied as food.

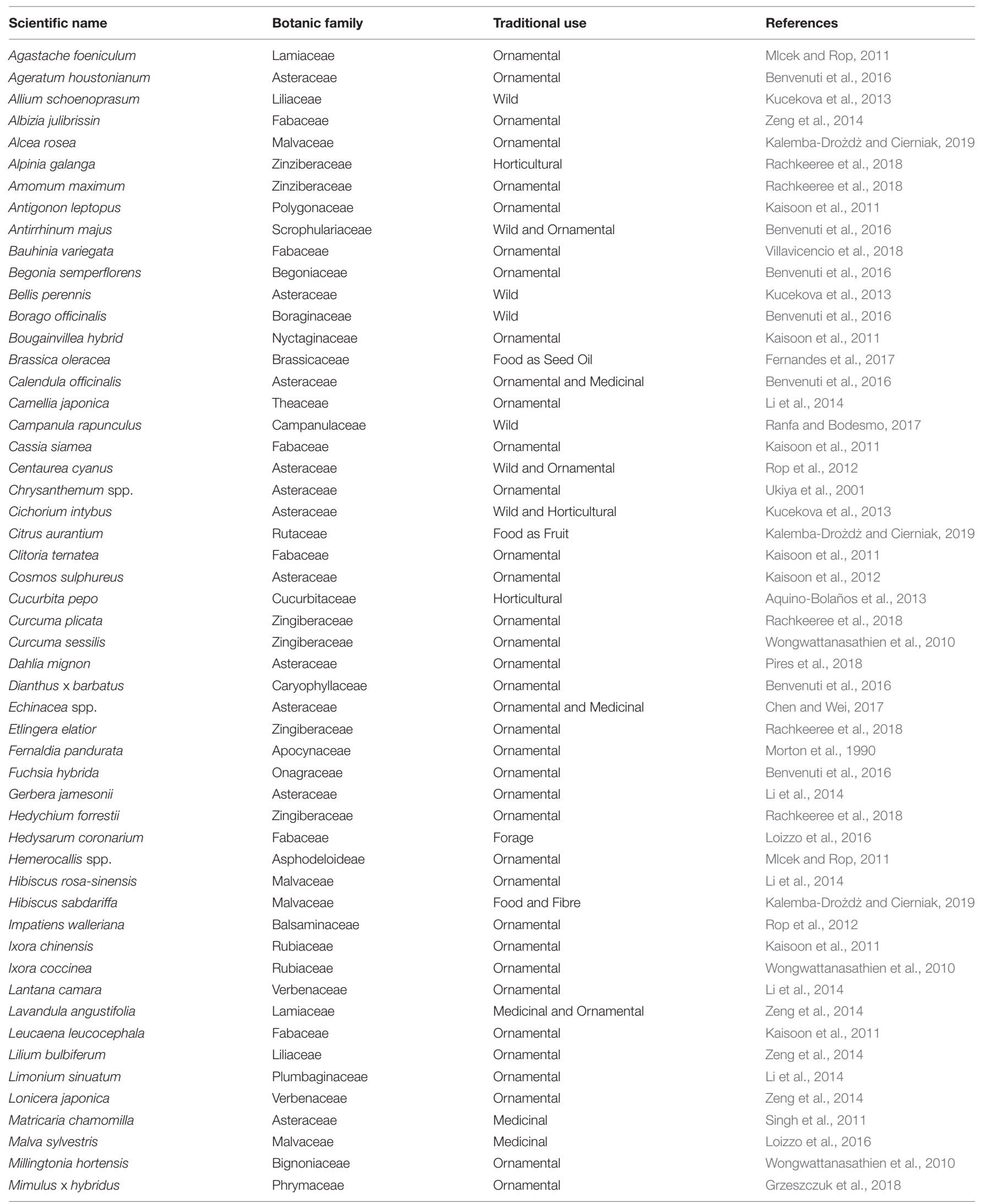


TABLE 1 | Continued

\begin{tabular}{|c|c|c|c|}
\hline Scientific name & Botanic family & Traditional use & References \\
\hline Nelumbo nucifera & Nelumbonaceae & Ornamental & Kaisoon et al., 2011 \\
\hline Malva sylvestris & Malvaceae & Medicinal & Barros et al., 2010 \\
\hline Monarda & Lamiaceae & Ornamental & Grzeszczuk et al., 2018 \\
\hline Oxalis corymbosa & Oxalidaceae & Ornamental & Li et al., 2014 \\
\hline Pelargonium peltatum & Geraniaceae & Ornamental & Benvenuti et al., 2016 \\
\hline Petunia $\times$ hybrida & Solanaceae & Ornamental & Benvenuti et al., 2016 \\
\hline Plumeria obtusa & Apocynaceae & Ornamental & Kaisoon et al., 2011 \\
\hline Primula vulgaris & Primulaceae & Wild and Ornamental & Kalemba-Drożdż and Cierniak, 2019 \\
\hline Prunella vulgaris & Lamiaceae & Wild & Zeng et al., 2014 \\
\hline Punica granatum & Punicaceae & Ornamental and Food as Fruit & Wongwattanasathien et al., 2010 \\
\hline Rhinacanthus nasutus & Acanthaceae & Ornamental & Wongwattanasathien et al., 2010 \\
\hline Rhododendron simsii & Ericaceae & Ornamental & Li et al., 2014 \\
\hline Robinia pseudoacacia & Fabaceae & Ornamental & Mlcek and Rop, 2011 \\
\hline Rosa odorata & Rosaceae & Ornamental crop & Rop et al., 2012 \\
\hline Salvia pratensis & Lamiaceae & Wild and Ornamental & Kucekova et al., 2013 \\
\hline Salvia splendens & Lamiaceae & Ornamental & Li et al., 2014 \\
\hline Sambucus nigra & Caprifoliaceae & Wild and Ornamental & Kucekova et al., 2013 \\
\hline Strelitzia reginae & Strelitziaceae & Ornamental & Li et al., 2014 \\
\hline Syringa vulgaris & Oleaceae & Ornamental & Mlcek and Rop, 2011 \\
\hline Syzygium malaccense & Myrtaceae & Ornamental & Wongwattanasathien et al., 2010 \\
\hline Tagetes erecta & Asteraceae & Ornamental & Benvenuti et al., 2016 \\
\hline Tagetes patula & Asteraceae & Ornamental & Kalemba-Drożdż and Cierniak, 2019 \\
\hline Tamarix gallica & Tamaricaceae & Ornamental & Ksouri et al., 2009 \\
\hline Taraxacum officinale & Asteraceae & Wild and Medicinal & Kucekova et al., 2013 \\
\hline Telosma minor & Apocynaceae & Ornamental & Kaisoon et al., 2011 \\
\hline Tragopogon pratensis & Asteraceae & Wild & Kucekova et al., 2013 \\
\hline Trifolium pratense & Fabaceae & Wild and Forage & Kalemba-Drożdż and Cierniak, 2019 \\
\hline Trifolium repens & Fabaceae & Wild and Forage & Kucekova et al., 2013 \\
\hline Tropaeolum majus & Tropaeolaceae & Ornamental & Benvenuti et al., 2016 \\
\hline Tulipa spp. & Liliaceae & Ornamental & Mlcek and Rop, 2011 \\
\hline Viola $\mathrm{x}$ wittrockiana & Violaceae & Ornamental & Benvenuti et al., 2016 \\
\hline Viola arvensis & Violaceae & Wild and Ornamental & Kucekova et al., 2013 \\
\hline Viola cornuta & Violaceae & Ornamental & Kalemba-Drożdż and Cierniak, 2019 \\
\hline Viola tricolor & Violaceae & Wild & Koike et al., 2015 \\
\hline Zingiber spp. & Zingiberaceae & Horticultural & Rachkeeree et al., 2018 \\
\hline
\end{tabular}

typical of species such as Tagetes erecta (Šivel et al., 2014) and Tropaeolum majus (Niizu and Rodriguez-Amaya, 2005).

A further category of nutraceutical substances consisting of simple phenolic acids should also be considered. In fact phenolic acids and flavonoids are the most common phenolic compounds with prevalent nutraceutical activity. These substances are very widespread in flowers, especially in the botanical genus Rosa (Zheng et al., 2018), and contribute energetically to antioxidant power. For example, in ornamental species such as Tropaeolum majus, Tagetes erecta, and Spilanthes oleracea the phenolic content is closely related to the overall antioxidant activity found in the various species (Navarro-González et al., 2015). This biological activity is also due to the content of vitamins A, C, and $\mathrm{E}$ in the flower tissues (Mlcek and Rop, 2011), such as in rose (Rosa hybrida) petal extracts (Hou et al., 2014). These flower vitamins could limit or prevent nutritional deficiencies due to a prolonged standardized diet (Rop et al., 2012). In particular, vitamin $\mathrm{E}$ was found to consist mainly of four tocopherols $(\alpha-, \beta-$, $\gamma$-, and $\delta$-tocopherol) and two tocotrienols ( $\beta$ - and $\gamma$-tocotrienol) in Borago officinalis, Camellia japonica, Centaurea cyanus, and Viola $\mathrm{x}$ wittrockiana (Fernandes et al., 2020).

A further phytochemical category that characterizes flowers is that of essential oils, which are a very complex natural mixture with a high content of terpenes (Bakkali et al., 2008). Essential oils are not exclusive to aromatic species, as in the case of basil (Chalchat and Özcan, 2008), but are also widespread in many other ornamental species, such as Chrysanthemum indicum (Lee et al., 2015), thus generating interest both for food uses and pharmaceutical applications (Voon et al., 2012). Besides being primarily responsible for imparting aroma, essential oils also have a strong antimicrobial activity.

Finally, the mineral content of flowers is significant (Fernandes et al., 2017) both in terms of macronutrients (phosphorus, potassium, calcium, and magnesium) and 


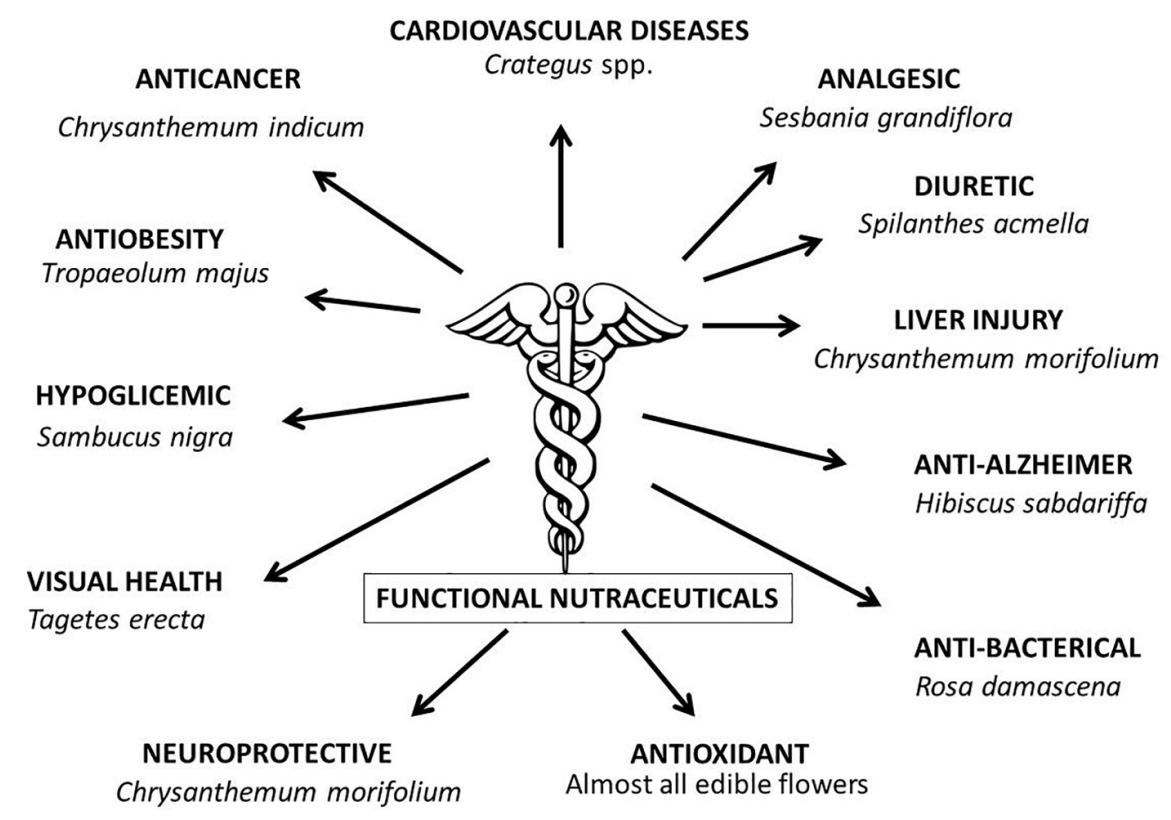

FIGURE 1 | Functional nutraceuticals scientifically proven on human health.

micronutrients (iron, manganese, copper, and zinc). For example, flowers belonging to the botanic genus Chrysanthemum, Dianthus or Viola are particularly rich in these substances, especially in terms of potassium (Rop et al., 2012). Some species belonging to the botanical genus Monarda are also very rich in calcium and magnesium (Grzeszczuk et al., 2018). However, zinc, which is particularly found in Tagetes patula flowers (Rop et al., 2012), content is of nutraceutical importance, since zinc is heavily involved in modulating the immune function (Haase and Rink, 2014).

It should be emphasized that these nutraceutical phytochemicals can be useful not only as food but also as drugs following recent processing and extraction of bioactive compounds by novel technologies (Zhao et al., 2019).

\section{ECOLOGICAL ROLE OF FLOWER PHYTOCHEMICALS}

Almost all ornamental flowers have evolved chromatically showy corollas as a strategy to attract pollinators [mainly bees, solitary bees, bumblebees, hoverfly (Diptera Syrphidae), bee fly (Diptera Bombyliidae), and butterfly], since they are responsible for the gene flow within each species (Figure 2). Indeed this showiness is a sort of "publicity" to facilitate their identification. The "eye catching" corollas stand out in the green of the vegetation behind. Plant biomass is dominated by the color green due to the chlorophyll pigments, and the other pigments (flavonoids and carotenoids) that develop corollas, facilitate flower recognition. This is why large and highly pigmented flower species, which have evolved as an entomogamy strategy (Vanbergen and Initiative, 2013), is the portion of plant biodiversity that has aroused the most interest as ornamental use. Very often pigments such as carotenoids and anthocyanins are typically abundant in species that have little or no possibility of self-pollination due to pollen incompatibility within the same plant (Busch and Schoen, 2008), as occurs in Centaurea cyanus (Bellanger et al., 2015).

The high pigmentation of the flower corollas derives from a co-evolution mechanism with a mutual reward: (i) advertising for pollinators by increasing the degree of seed set and (ii) evolution of the visual system of pollinators thus facilitating

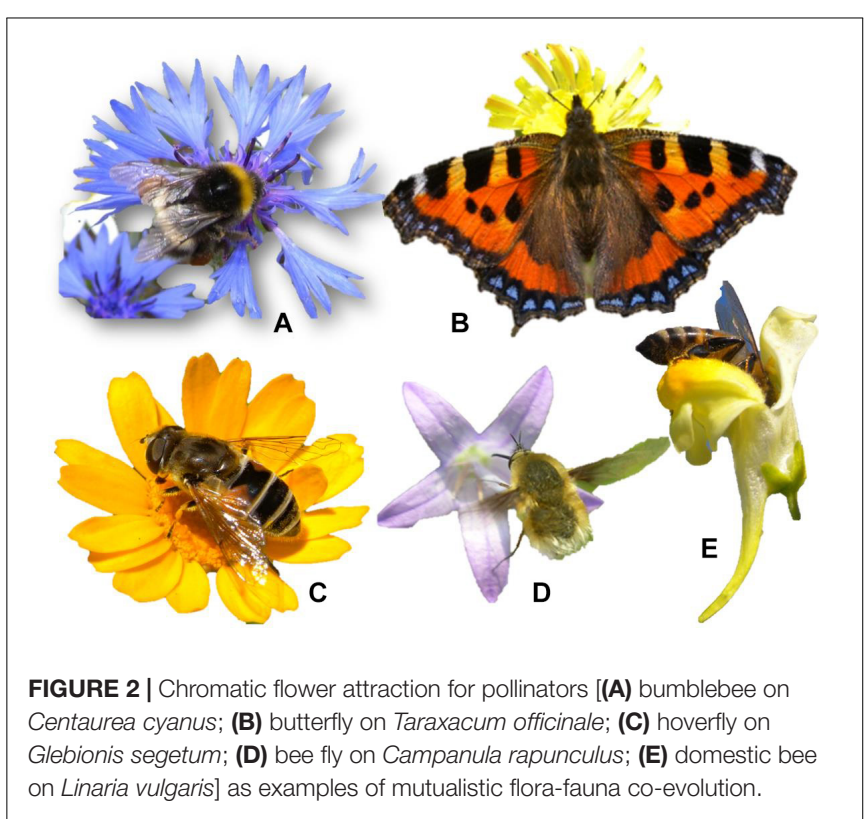


the food detection (pollen and / or nectar). This also happens in intensely colored fruits (blackberries, blueberries, raspberries, etc.) in which the pigmentation derives from a flora-fauna coevolution that facilitates fruit recognition and attractiveness thus leading to frugivorous dispersal (Shanahan et al., 2001). In this case the reward for frugivores consists of the fruit tissues surrounding the seeds. Flower and fruit pigmentation is thus a real "advertising" strategy for flowers and fruits, which are more easily identified in the green background of the leaf canopy.

From a phytochemical point of view, the wide range of possible colors is generated by the quantity and quality of three categories of pigments: carotenoids (conferring red and yellow colors), anthocyanins (purple and blue), and other flavonoids (white and yellow). The range of flower colors used as a "recognition strategy" is not accidental, since some colors are frequently used while others are decidedly less chosen by the various species. This is because insects have a visual system which, depending on the category of insect considered (bees, Diptera, Lepidoptera, etc.), with an optimal "vision" in certain bands of the light spectrum and overall in the ultraviolet region (Chittka and Raine, 2006).

In addition to the bright chromaticity of the flower corollas, flower scents also play an important role in terms of attractiveness (Pichersky and Gershenzon, 2002). The ecological strategy of emitting highly volatile substances, in order to be visualized at a distance, was subjected to co-evolution between flowers and pollinators (Dötterl and Vereecken, 2010). Does this therefore mean that there is also something in common with pollinators in terms of organoleptic taste perception? It is surprising that this makes flowers attractive to humans too, given that they are the play of colors and the scents showing the same attractiveness perceived by many pollinators, especially bees and bumblebees (Leonard and Masek, 2014).

The scent of flowers derives from a great complexity of chemical substances (Knudsen et al., 2006), which belong to different classes of compounds, such as aliphatics, benzenoids, phenylpropanoids, and terpenes (mono- and sesquiterpenes). The most common "highly volatile" compounds are made up of some monoterpenes such as limonene, (E) - $\beta$-ocimene, myrcene, linalool, $\alpha$ - and $\beta$-pinene. Benzenoids are also very widespread such as benzaldehyde, methyl 2-hydroxybenzoate (methyl salicylate) as well as benzyl alcohol, 2-phenyl ethanol, and sesquiterpene caryophyllene.

To sum up, insect pollinated flora has evolved a chromatic and olfactory attraction not only for pollinators, but also for humans. Indeed flower shapes, colors and scents generate a high emotional impact (Haviland-Jones et al., 2005), whose psychological aspects have become synergistic with the nutritional ones.

\section{NUTRITIONAL VALUE OF THE DIFFERENT FLOWER STRUCTURES}

The heterogeneity of the botanical structures of several species of flowers is closely connected with their respective chemical diversity (Figure 3). This phytochemical complexity makes edible

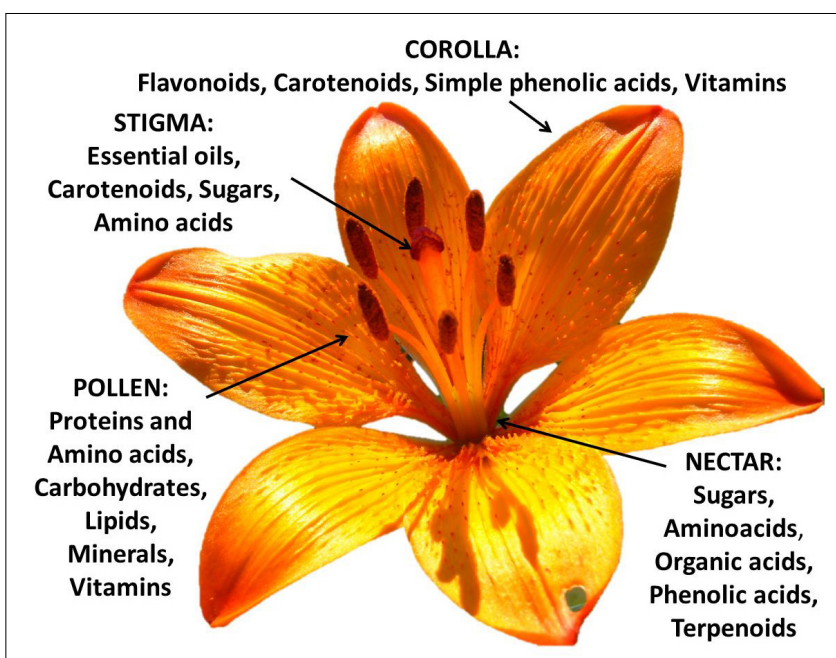

FIGURE 3 | Prevalent phytochemicals of the different components of the edible Lilium bulbiferum flower (corolla, stigma, pollen, and nectar).

flowers especially interesting. Their nutritional value is provided by the pollen (rich in proteins and amino acids), nectar (rich in sugars), and corolla tissues (rich in pigments, vitamins, and microelements). This mixture of primary (sugars, proteins, etc.) and secondary metabolites (vitamins, pigments, etc.) helps prevent nutritional deficiencies in the human diet (Pires et al., 2019). Below we analyze the phytochemical properties of each flower component.

Although constituting a small part of the flower, pollen is mostly rich in carbohydrates (13-55\%), protein and amino acids (10-40\%), and to a lesser extent in polyunsaturated lipids (1-13\%), fiber and pectins, (0.3-20\%), minerals (2-6\%) and small amounts of other chemical substances including some important vitamins (2-5\%) such as $\beta$-carotene, thiamine, riboflavin, niacin, pantothenic acid, ascorbic acid, biotin, folic acid, and tocopherols (Campos et al., 2008). This phyto-complex indicates an important nutraceutical role of its bioactive properties for human health (Kroyer and Hegedus, 2001). Pollen shows antioxidant, anti-inflammatory, anticarcinogenic, antibacterial, antifungicidal, hepatoprotective, anti-atherosclerotic activities and modifies or regulates immune functions (Denisow and Denisow-Pietrzyk, 2016). It should be emphasized that although pollen is capable of generating allergies, this typically occurs in wind-pollinated species characterized by very small pollen capable of aerodispersion (Culley et al., 2002). On the contrary, the insect-pollinated species (as in the case of ornamental species) are characterized by larger pollen that can hardly cause allergy problems. On the other hand the use of pollen as a food rich in nutraceutical properties is well known (Llnskens and Jorde, 1997).

Despite its limited content in the whole flower, the nectar constitutes a balanced mixture of amino acids and sugars consisting of fructose, glucose, and sucrose (Pacini et al., 2003). The nectar also contains secondary metabolites such as organic acids, simple phenolic acids, and terpenoids (Nicolson et al., 
2007). Although stigmas are less important and poorly studied as a component of edible flowers, they have been found to contain essential oils in the case of Cucurbita pepo (Granero et al., 2005) and carotenoids in the well-known Crocus sativus (Melnyk et al., 2010). In addition, sugars and amino acids have been detected in the stigmatic secretions of pomaceous flowers (Pusey et al., 2008).

Lastly, the corolla is the main portion of the flower in terms of biomass. Consequently, the quantity and chemical composition of the phytochemicals present in their tissues provide a nutraceutical functionality to a specific species. This typically highly pigmented flower portion contributes most of the health properties in terms of antioxidant activity thanks to the wealth of anthocyanins, other flavonoids, carotenoids, simple phenolic acids, ascorbic acid (Garzón and Wrolstad, 2009), and other vitamins (Fernandes et al., 2020). This nutraceutical role of the corollas has meant that most species used as edible flowers have also been selected due to their flower size, as in the case of Nasturtium officinale, Petunia spp., Tagetes spp., Antirrhinum majus, and Viola $\mathrm{x}$ wittrockiana. However, the success of some of the many species with potentially edible flowers is due to the organoleptic impact perceived by consumers.

\section{DISCOVERING THE UNKNOWN TASTE OF FLOWERS}

The growing interest in edible flowers is motivated not only by decorative and nutraceutical objectives, but also by the desire for new flavors and new opportunities for gastronomic innovation. Some studies have identified the sensory profile of the flowers (Benvenuti et al., 2016), and these "panel tests" have highlighted not only the level of overall appreciation of some species of flowers but also the individual organoleptic characteristics (sweetness, spiciness, aroma, bitterness, consistency) as well as their similarity with other already known vegetables and/or spices. The flowers that were particularly appreciated were Tropaeolum majus, characterized by the spicy taste (similar to that of radish), while Ageratum houstonianum aroused a taste that was similar to a carrot. The Begonia semperflorens was also of particular interest, which was decidedly sour, similar to lemon juice.

Other promising organoleptic results (Benvenuti et al., 2016) have been shown by Dianthus x barbatus which tastes similar to cloves, Calendula officinalis which is similar to saffron, and Pelargonium peltatum similar to grapefruit. Other species, have been perceived as having a completely new taste such as the flowers of Petunia hybrida and Viola $\mathrm{x}$ wittrockiana. In some cases the consistency of the flower was not liked, for example Fuchsia hybrida, however, a gastronomic analysis of these flowers (comminution, seasoning, mixed with other vegetables, cooking, etc.) might improve their palatability. Overall the flowers that seem to simultaneously satisfy aroma and consistency are Nasturtium officinale, Viola $\mathrm{x}$ wittrockiana, Ageratum houstonianum, and Begonia semperflorens.

Tasting these "new vegetables" has generated a mixture of enthusiasm and curiosity, together with an understandable mistrust in the strange shapes, consistency, flavors and aromas.
People's negative attitudes toward new foods comes under the term "neophobia." This mistrust of new food could be mitigated by food education in children, which is the age when our taste perception begins to be formed (Mustonen and Tuorila, 2010). The discovery of new flavors, especially in children, could stimulate the appreciation of flowers, thus preventing them from being regarded as too unusual. In fact, an innate instinct to avoid unknown tastes hinders a full success of this "new food" (Pliner and Hobden, 1992) especially in children (Dovey et al., 2008). Flowers need to be combined with other foods in order to make their acceptance easier. The optimal combinations between flower dishes and a specific type of wine or beer could also help to enhance each other's characteristics.

\section{WHICH FLOWER SPECIES ARE CURRENT OR POTENTIAL "NEW FOODS"?}

As to which flowers can be eaten, there are no clear boundaries between edible species, and it depends on the taste of the consumer. The only objective characteristic is their non-toxicity, which will be examined in the next section. To limit the species with edible flowers there are various books (Barash, 1993; Roberts, 2000) and scientific publications (Table 2) which list the flowers with traditional ethnobotanical uses as food (Mulík and Ozuna, 2020) and/or whose phytochemical aspects have been recently discovered.

Most species used as edible flowers are ornamental species. This derives both from their wide availability, as widely cultivated species, and due to the fact that their ornamentality is closely linked to their large corollas and/or the high number of flowers or inflorescences per plant. Species with large-sized flowers are, for example, Hibiscus rosa-sinensis, Lilium bulbiferum, Petunia $\mathrm{x}$ hybrida, Tagetes erecta, Tropaeolum majus, and Viola $\mathrm{x}$ wittrockiana.

Other species have smaller but extremely numerous flowers such as Oxalis corymbosa, Impatiens walleriana, Dianthus $\mathrm{x}$ barbatus, Limonium sinuatum, Viola cornuta, Ageratum houstonianum, and Agastache foeniculum.

Some species with edible flowers, although sometimes also used as ornamentals, are typical medicinal crops such as Matricaria chamomilla, Calendula officinalis, Taraxacum officinalis, and Lavandula angustifolia. In these cases the flowers are gathered in inflorescences and are small but very aromatic, and can be used in chromatically and aromatically innovative gastronomic creations.

In other cases, the edible flowers belong to common horticultural species which have been traditionally (Cucurbita pepo), or recently (Cichorium inthybus), used as food. There are also species with edible flowers that are cultivated as forage such as Trifolium repens and Trifolium pratense.

Finally, there is a vast biodiversity of wild species which are also sometimes cultivated similarly to what occurs for wild herbs (Schulp et al., 2014). These are species found in natural (or partially anthropized) ecosystems such as Bellis perennis, Borago officinalis, Campanula rapunculus, Allium 
TABLE 2 | Poisonous, toxic, and anti-nutritional activity of ornamental species.

\begin{tabular}{|c|c|c|c|c|}
\hline Scientific name & Botanic family & Main phytochemicals & Degree of toxicity & References \\
\hline Convallaria majalis & Liliaceae & Glycosides & Toxic & Löffelhardt et al., 1979 \\
\hline Asphodelus spp. & Liliaceae & Glycosides & Toxic & Safder et al., 2009 \\
\hline Ornithogalum spp. & Liliaceae & Glycosides & Toxic & Botha et al., 2000; Slenter et al., 2019 \\
\hline Colchicum autumnale & Liliaceae & Alkaloids & Poisonous & Klintschar et al., 1999 \\
\hline Conium maculatum & Apiaceae & Alkaloids & Poisonous & Vetter, 2004 \\
\hline Laburnum anagyroides & Fabaceae & Alkaloids & Poisonous & Schep et al., 2009 \\
\hline Narcissus spp. & Amaryllidaceae & Alkaloids & Toxic & Bastida et al., 2006 \\
\hline Digitalis spp. & Scrophulariaceae & Glycosides & Poisonous & Yang et al., 2012 \\
\hline Datura spp. & Solanaceae & Alkaloids & Toxic & Krenzelok, 2010 \\
\hline Atropa belladonna & Solanaceae & Alkaloids & Toxic & Kwakye et al., 2018 \\
\hline Euphorbia pulcherrima & Euphorbiaceae & Terpenes & Toxic & Smith-Kielland et al., 1996 \\
\hline Vinca spp. & Apocynaceae & Alkaloids & Toxic & Gutowski et al., 1995 \\
\hline Nerium oleander & Apocynaceae & Glycosides & Poisonous & Barbosa et al., 2008 \\
\hline Hyoscyamus spp. & Solanaceae & Alkaloids & Toxic & Shams et al., 2017 \\
\hline Anemone spp. & Ranunculaceae & Alkaloids & Toxic & Turner, 1984 \\
\hline Ranunculus spp. & Ranunculaceae & Alkaloids & Toxic & Turner, 1984 \\
\hline Helleborus spp. & Ranunculaceae & Alkaloids & Toxic & Turner, 1984 \\
\hline Aconitum napellus & Ranunculaceae & Alkaloids & Toxic & Turner, 1984 \\
\hline Yucca filifera & Liliaceae & Inhibitory enzymes & Anti-nutritional & Sotelo et al., 2007 \\
\hline Erythrina spp. & Fabaceae & Inhibitory enzymes & Anti-nutritional & Sotelo et al., 2007 \\
\hline Cyclamen spp. & Primulaceae & Glycosides & Toxic & Spoerke et al., 1987 \\
\hline Paeonia spp. & Paeoniaceae & Alkaloids & Toxic & Sadati Lamardi et al., 2018 \\
\hline Rhododendron spp. & Ericaceae & Terpenoids & Toxic & Popescu and Kopp, 2013 \\
\hline Mirabilis jalapa & Nyctaginaceae & Inhibitory enzymes & Anti-nutritional & Kowalska et al., 2007 \\
\hline Jasminum spp. & Oleaceae & Glycosides & Toxic & Bhushan et al., 2014 \\
\hline Callistemon citrinus & Myrtaceae & Terpenes & Toxic & Bhushan et al., 2014 \\
\hline Hydrangea macrophylla & Hydrangeaceae & Glycosides & Toxic & Ito et al., 2009 \\
\hline Wisteria sinensis & Fabaceae & Glycosides & Toxic & Mohamed et al., 2011 \\
\hline Cytisus scoparius & Fabaceae & Alkaloids & Toxic & Wink et al., 1982 \\
\hline
\end{tabular}

schoenoprasum, Anthirrhinum majus, and Prunella vulgaris. Sometimes species with edible flowers even include weeds of traditional agro-ecosystems such as Centaurea cyanus and Viola tricolor. These insect-pollinated weeds are often rare and used as an "indicator" of the health and biological sustainability of agroecosystems (Rollin et al., 2016), and consequently their food use could facilitate their germplasm conservation.

\section{WHICH SPECIES SHOULD BE AVOIDED?}

Some plant species have evolved toxicity and/or poisonousness in order to defend themselves from both parasitic and/or pathogenic organisms and, above all, from herbivorous fauna. Consequently, great care must be taken not to confuse the beauty of the flowers with their usability as food since some may be toxic or poisonous for both humans and animals (Tamilselvan et al., 2014).

The phytochemicals responsible for toxicity belong above all to the chemical categories of alkaloids, saponins, terpenes and glycosides (Mithöfer and Boland, 2012). These species mainly belong to the botanical families of liliaceae, amaryllidaceae, apiaceae, fabaceae, scrophulariaceae, solanaceae, euphorbiaceae, apocynaceae, and ranunculaceae (Table 2). While in some botanical families, almost all species have frequently high toxicity and/or poisonousness (such as ranunculaceae, apocynaceae, euphorbiaceae, and ranunculaceae), the toxic species of other botanical families such as liliaceae, fabaceae, scrophulariaceae and solanaceae are rare, while many others, belonging to these botanical taxa, are widely used as food or as medicine, including both the flowers and other parts of the plant.

The ranunculaceae family is one example of a botanical family rich in ornamental species but which are almost always toxic. These include the various species belonging to the botanical genus Anemone (Anemone coronaria, Anemone hortensis, Anemone nemorosa, etc.) the genera Ranunculus, Aquilegia, Helleborus and above all the poisonous species belonging to the genus Aconitum.

Other botanical families have species whose flowers are edible, but other species that are toxic. For example the family of liliaceae includes species with edible flowers (for example Lilium bulbiferum, Allium schoenoprasum, Tulipa spp.). While in other cases the ingestion of the flowers can cause toxicity (for example Convallaria majalis, Asphodelus spp., Ornithogalum spp., and Colchicum autumnale).

Another real risk for humans is toxic nectar (Adler, 2000), since in some cases pyrrolizidine alkaloids have been detected in honey (Edgar et al., 2002; Dübecke et al., 2011). This problem 
appears to be linked above all to species belonging to the botanical family of Boraginaceae such as in Heliotropium amplexicaule (Carpinelli de Jesus et al., 2019) and Echium vulgare (Lucchetti et al., 2016). Such hepatotoxic pyrrolizidine alkaloids have also been detected in pollen, although to date this problem has only been detected in a few species (Kast et al., 2018) belonging to the botanical genus Echium and in species belonging to other families such as Asteraceae (Senecio spp. and Eupatorium cannabinum).

Additional interest in edible flowers is due not so much to the toxic phytochemicals but to anti-nutritional phytochemicals capable of altering the normal metabolism (Sotelo et al., 2007). For example, a study carried out in Mexico on various "endangered" species, showed that although the splendid flowers of the Yucca filifera, which are sometimes used as a food in local dishes, contain undesirable saponins with hemolytic activity. Agave salmiana, on the other hand, shows hemagglutinating activity (Barriada-Bernal et al., 2014). In addition, some species of fabaceae belonging to the botanical genus Erythrina (Erythrina americana and Erythrina caribaea) contain trypsin inhibitor enzymes.

Further studies are thus needed to reliably identify those species that are truly edible. However, some species that are "to be avoided" may also have a purpose as, as according to the Swiss doctor, Paracelsus (1493-1541): “The dose makes the poison." There are in fact many uses of toxic flowers as medicines, which could constitute a further innovation chain in the agronomic and pharmaceutical sector.

\section{WHICH CROPPING SYSTEMS ARE SUITABLE FOR EDIBLE FLOWERS?}

Producing edible flowers clearly requires organic cultivation systems (Kelley and Biernbaum, 2000) since current and potential consumers are particularly attracted to "novel foods" that are both nutraceutical and completely pesticide free. In fact some studies (Chen, 2009) have shown that a healthy lifestyle mediates health consciousness and attitude toward organic foods. This is why some "nutrient management" techniques focused on organically grown edible flowers (Kelley and Biernbaum, 2000) have been tested in the same way as conventional vegetables (Van Bruggen et al., 2016). However, similarly to common leaf vegetables for fresh consumption, flowers must ensure food safety also from a biological point of view, which could be jeopardized by the use of organic fertilizers that are often rich in unwanted microorganisms (Sharma and Reynnells, 2018). This is particularly important for all ready-to-eat vegetables (Sagoo et al., 2001).

The methods of distribution of organic fertilizers must not come into contact with the epigean part of the plant in any way, thus preventing them from being contaminated in terms of the microbial load.

Unfortunately there have not been sufficient studies on verifying the food safety in microbiological terms of edible flowers grown with organic cropping systems. This is of key importance since one study has verified that flowers grown without the aid of any pesticide are safe from a chemical point of view, but not always a biological one. In fact, unwanted microorganisms such as Enterobacter hormaechei, Acinetobacter calcoaceticus, Enterobacter ludwigii, Enterobacter asburiae, Enterobacter cowanii, Pseudomonas aeruginosa, Salmonella enterica, and Bacillus amyloliquefaciens (Wetzel et al., 2010) have sometimes been found on "organically grown" flowers. Consequently, prevention from the microbiological contamination of edible flowers is a major problem that merits further studies to ensure greater food safety.

In addition to microbiological contamination, pesticide residues such as sulphite, dimethoate and $\mathrm{N}, \mathrm{N}$-diethyl-metatoluamide (Matyjaszczyk and Śmiechowska, 2019) are extremely undesirable chemicals that are widely used in conventional cropping systems of ornamental crops not intended for human consumption. However, adopting the wide range of crop defense strategies for edible flower production using organic methods is a positive step (Dayan et al., 2009). A further agronomic strategy is to identify species and cultivars that are less susceptible to pathologies such as, the botanic genus Rosa (Friedman et al., 2010).

Lastly, the vast biodiversity of species with edible flowers has different biological characteristics both in terms of thermal requirements, photoperiod, biological cycle (annual and perennial), and time and duration of flowering. This complexity involves a diversified agronomic management especially according to the reachable size of the various crops since they are not exclusively herbaceous but also include shrubs and trees. For example ornamental crops such as Rosa spp., Camellia japonica, Hibiscus rosa-sinensis, Sambucus nigra, and Bougainvillea hybrida are shrubs, while are Robinia pseudo-acacia and Cassia siamea are ornamental trees with edible flowers. These species are thus almost exclusively cultivable in the open air and therefore their flowering calendars are very rigid and not suitable for ensuring the availability of edible flowers throughout the year.

Unfortunately, the seasonality of flower production is not very compatible with their commercial success due to their unavailability for long periods. Edible flowers also have very sensitive organoleptic characteristics and are not suitable for storage or as frozen or dried products. However, most of the species with edible flowers are herbaceous and thus are suitable for cultivation both in the open air and in the greenhouse, thus ensuring much longer flowering calendars. Basically, species mainly belonging to this last category of herbaceous species are the main candidates to respond to market needs, since they are available throughout the year. This amplitude and flexibility of the blooms are crucial for use as ingredients in various dishes for long periods of the year both for "home cooking" and in "gourmet cuisine."

A parallel activity for edible flowers is to satisfy the needs of urban agriculture (Eigenbrod and Gruda, 2015). Urban cropping systems for edible flowers are capable of providing both: (i) the maximum degree of freshness (ready-to-eat locally produced at "zero-kilometers") and (ii) an increase in urban biodiversity especially in terms of pollinators. Edible flowers represent the ideotype of "new vegetables" for "urban edible landscapes" (Specht et al., 2014) with a dual role of being both ornamental and a source of nutritious food. 


\section{WHAT DO CONSUMERS PREFER AND WHAT KIND OF PACKAGING SHOULD BE USED?}

The standard packaging of edible flowers usually involves transparent polyethylene trays in order to enhance their chromatic impact. Depending on the species, the shelf life, is around 7-10 days at around $2-5^{\circ} \mathrm{C}$ (Kelley et al., 2003). This low temperature keeps the antioxidant activity almost unchanged as demonstrated in Tropaeolum majus (Friedman et al., 2005). The organoleptic alteration that occurs during very long storage includes petal abscission and discoloration, flower wilt, dehydration, and tissue browning. However, the shelf life can be extended by adding methylcyclopropene $(1-\mathrm{MCP})$ which delays senescence since is a non-toxic antagonist of ethylene, which binds to the ethylene receptors, thus interfering with ethylene mediated changes (Kou et al., 2012).

Post-harvest technologies such as high hydrostatic pressure (HHP) or irradiation (Fernandes et al., 2019) will become increasingly important in order to extend the marketing of edible flowers in terms of time and space. However, the commercial success of edible flowers derives not only from further studies on their shelf life, but also from marketing strategies that attract consumers to this surprising and unusual "new food."

Curiosity and aroma seem to be the parameters that most influence consumer attitudes toward the consumption of edible flowers as being "ready to eat" (Chen and Wei, 2017). Similarly, the combination of colors in the trays displayed on supermarket shelves also plays a crucial role in terms of attractiveness (Kelley et al., 2001). In particular, the combination of blue, yellow, and orange seems successful in influencing consumer choices. Transparent packaging plays a crucial role in highlighting the beauty of the heterogeneity of flower shapes and colors (Chen and Wei, 2017). Immediately after the visual impact of the package, the price is able to influence the consumer's choices. Finally, the size of the package plays a marginal role in influencing the behavior of potential consumers (Kelley et al., 2001). A further aspect of growing interest is to provide recipes that enhance the attraction of the flowers in three ways: (i) chromatic attractiveness, (ii) tastiness, and (iii) benefit for human health. Of course these may vary according to the cultural differences of the consumers (Rodrigues et al., 2017). The most appropriate criterion is to use well-known gastronomic creations for a specific "local" gastronomic culture (soups, pasta, bread, meat, fish, sweets, salads, ice cream, yogurt, herbal teas, etc.) in order to make more new food more familiar.

\section{REFERENCES}

Adler, L. S. (2000). The ecological significance of toxic nectar. Oikos 91, 409-420. doi: 10.1034/j.1600-0706.2000.910301.x

Aquino-Bolaños, E. N., Urrutia-Hernández, T. A., López Del Castillo-Lozano, M., Chavéz-Servia, J. L., and Verdalet-Guzmán, I. (2013). Physicochemical parameters and antioxidant compounds in edible Squash (Cucurbita Pepo) flower stored under controlled atmospheres. J. Food Qual. 36, 302-308. doi: $10.1111 /$ jfq. 12053

Bakkali, F., Averbeck, S., Averbeck, D., and Idaomar, M. (2008). Biological effects of essential oils-a review. Food Chem. Toxic. 46, 446-475. doi: 10.1016/j.fct.2007. 09.106

\section{CONCLUSION}

The biodiversity of ornamental and wild species with edible flowers is one of the most promising resources for gastronomic innovation aimed at offering new tastes and new combinations of flowers with other foods (including vegetables and meat, fish and types of beer and wines). Their nutraceutical potential benefits human health also in terms of a psychological impact by combining the beauty of flowers with their tastiness. Future studies will increasingly underline the nutraceutical potential of the various species of flowers that can prevent certain pathologies and thus be part of "personalized diets" aimed at specific health problems.

In summary, this review has highlighted some key aspects that can encourage a further affirmation of edible flowers trying to answer the following questions: which species are currently used (especially ornamental species), which have the characteristics of a future affirmation (many wild species with potential domestication), which ones are avoided (some toxic, poisonous species and / or with antinutritional substances), why they are rich in pigments (chromatic strategies to attract pollinators), why they are human health friendly (chemical nature and richness in nutraceutical pigments) and what agronomic perspectives can have (dedicated crops and urban "food" floriculture). Such answers will be able to help, in the near future, the agronomic challenge aimed at making possible the real availability in space and time of these emerging foods. Indeed, although both edible flowers and wild herbs are much cited by important traditional culinary uses, they are still hardly available today in large commercial distribution. Food safety in terms of the absence of both pesticides and pathogenic microorganisms (Nicolau and Gostin, 2015) will be of crucial importance for a complete affirmation of this still unusual food.

In conclusion, edible flowers - ornamental and wild - have the potential of providing an important "ecosystem service" to satisfy the growing desire for new organoleptic discoveries that are healthy both from a biological and psychological point of view.

\section{AUTHOR CONTRIBUTIONS}

Both authors contributed to the investigation, data curation, supervision, and writing of this review.

Barash, C. W. (1993). Edible Flowers: From Garden to Palate. Beltsville, MA: Fulcrum publ.

Barbosa, R. R., Fontenele-Neto, J. D., and Soto-Blanco, B. (2008). Toxicity in goats caused by oleander (Nerium oleander). Res. Vet. Sci. 85, 279-281. doi: 10.1016/j.rvsc.2007.10.004

Barriada-Bernal, L. G., Almaraz-Abarca, N., Delgado-Alvarado, E. A., GallardoVelázquez, T., Ávila-Reyes, J. A., Torrres-Morán, M. I., et al. (2014). Flavonoid composition and antioxidant capacity of the edible flowers of Agave durangensis (Agavaceae). CytA J. Food 12, 105-114. doi: 10.1080/19476337. 2013.801037

Barros, L., Carvalho, A. M., and Ferreira, I. C. (2010). Leaves, flowers, immature fruits and leafy flowered stems of Malva sylvestris: a comparative study of the 
nutraceutical potential and composition. Food Chem. Toxicol. 48, 1466-1472. doi: 10.1016/j.fct.2010.03.012

Bastida, J., Lavilla, R., and Viladomat, F. (2006). Chemical and biological aspects of Narcissus alkaloids. Alkaloids 63, 87-179. doi: 10.1016/S1099-4831(06)63003-4

Bellanger, S., Guillemin, J. P., Touzeau, S., and Darmency, H. (2015). Variation of inbreeding depression in Centaurea cyanus L., a self-incompatible species. Flora 212, 24-29. doi: 10.1016/j.flora.2015.02.003

Benvenuti, S., Bortolotti, E., and Maggini, R. (2016). Antioxidant power, anthocyanin content and organoleptic performance of edible flowers. Sci. Hortic. 199, 170-177. doi: 10.1016/j.scienta.2015.12.052

Bhushan, B., Sardana, S., and Bansal, G. (2014). Acute and sub-acute toxicity study of Clerodendrum Inerme, Jasminum mesnyi Hance and Callistemon citrinus. J. Acute Dis. 324:327. doi: 10.1016/S2221-6189(14)60069-X

Botha, C. J., Schultz, R. A., Van der Lugt, J. J., and Archer, C. (2000). A krimpsiektelike syndrome in small stock poisoned by Ornithogalum toxicarium Archer \& Archer. J. S. Afr. Vet. Assoc. 71, 6-9. doi: 10.4102/jsava.v71i1.668

Busch, J. W., and Schoen, D. J. (2008). The evolution of self-incompatibility when mates are limiting. Trends Plant Sci. 13, 128-136. doi: 10.1016/j.tplants.2008. 01.002

Campos, M. G., Bogdanov, S., de Almeida-Muradian, L. B., Szczesna, T., Mancebo, Y., Frigerio, C., et al. (2008). Pollen composition and standardisation of analytical methods. J. Apic. Res. 47, 154-161. doi: 10.1080/00218839.2008. 11101443

Carpinelli de Jesus, M., Hungerford, N. L., Carter, S. J., Anuj, S. R., Blanchfield, J. T., De Voss, J. J., et al. (2019). Pyrrolizidine alkaloids of Blue Heliotrope (Heliotropium amplexicaule) and their presence in Australian honey. J. Agric. Food Chem. 67, 7995-8006. doi: 10.1021/acs.jafc.9b02136

Chalchat, J. C., and Özcan, M. M. (2008). Comparative essential oil composition of flowers, leaves and stems of basil (Ocimum basilicum L.) used as herb. Food Chem. 110, 501-503. doi: 10.1016/j.foodchem.2008.02.018

Chen, G. L., Chen, S. G., Xie, Y. Q., Chen, F., Zhao, Y. Y., Luo, C. X., et al. (2015). Total phenolic, flavonoid and antioxidant activity of 23 edible flowers subjected to in vitro digestion. J. Funct. Foods 17, 243-259. doi: 10.1016/j.jff.2015.05.028

Chen, M. F. (2009). Attitude toward organic foods among Taiwanese as related to health consciousness, environmental attitudes, and the mediating effects of a healthy lifestyle. Brit. Food J. 111, 165-178. doi: 10.1108/00070700910931986

Chen, N. H., and Wei, S. (2017). Factors influencing consumers' attitudes towards the consumption of edible flowers. Food Qual. Prefer. 56, 93-100. doi: 10.1016/ j.foodqual.2016.10.001

Chen, Q., Xu, B., Huang, W., Amrouche, A. T., Maurizio, B., Simal-Gandara, J., et al. (2020). Edible flowers as functional raw materials: a review on antiaging properties. Trends in Food Sci. Tech. 106, 30-47. doi: 10.1016/j.tifs.2020. 09.023

Chittka, L., and Raine, N. E. (2006). Recognition of flowers by pollinators. Curr. Opin. Plant Biol. 9, 428-435. doi: 10.1016/j.pbi.2006.05.002

Culley, T. M., Weller, S. G., and Sakai, A. K. (2002). The evolution of wind pollination in angiosperms. Trends Ecol. Evol. 17, 361-369. doi: 10.1016/S01695347(02)02540-5

Dayan, F. E., Cantrell, C. L., and Duke, S. O. (2009). Natural products in crop protection. Bioorg Med. Chem. 17, 4022-4034. doi: 10.1016/j.bmc.2009.01.046

Denisow, B., and Denisow-Pietrzyk, M. (2016). Biological and therapeutic properties of bee pollen: a review. J. Sci. Food Agric. 96, 4303-4309. doi: 10. $1002 /$ jsfa.7729

Dötterl, S., and Vereecken, N. J. (2010). The chemical ecology and evolution of bee-flower interactions: a review and perspectives. Can. J. Zool. 88, 668-697. doi: 10.1139/Z10-031

Dovey, T. M., Staples, P. A., Gibson, E. L., and Halford, J. C. (2008). Food neophobia and 'picky/fussy' eating in children: a review. Appetite 50, 181-193. doi: 10.1016/j.appet.2007.09.009

Dübecke, A., Beckh, G., and Lüllmann, C. (2011). Pyrrolizidine alkaloids in honey and bee pollen. Food Addit. Contam. A 28, 348-358. doi: 10.1080/19440049. 2010.541594

Edgar, J. A., Roeder, E., and Molyneux, R. J. (2002). Honey from plants containing pyrrolizidine alkaloids: a potential threat to health. J. Agric. Food Chem. 50, 2719-2730. doi: 10.1021/jf0114482

Eigenbrod, C., and Gruda, N. (2015). Urban vegetable for food security in cities. a review. Agron. Sustain. Dev. 35, 483-498. doi: 10.1007/s13593-0140273-y
Falla, N. M., Contu, S., Demasi, S., Caser, M., and Scariot, V. (2020). Environmental Impact of Edible flower production: a case study. Agronomy 10, 579. doi: 10. 3390/agronomy10040579

Fernandes, L., Casal, S., Pereira, J. A., Saraiva, J. A., and Ramalhosa, E. (2017). Edible flowers: A review of the nutritional, antioxidant, antimicrobial properties and effects on human health. J. Food Compos. Anal. 60, 38-50. doi: 10.1016/j. jfca.2017.03.017

Fernandes, L., Ramalhosa, E., Pereira, J. A., Saraiva, J. A., and Casal, S. (2020). Borage, camellia, centaurea and pansies: Nutritional, fatty acids, free sugars, vitamin E, carotenoids and organic acids characterization. Food Res. Int. 132:109070. doi: 10.1016/j.foodres.2020.109070

Fernandes, L., Saraiva, J. A., Pereira, J. A., Casal, S., and Ramalhosa, E. (2019). Post-harvest technologies applied to edible flowers: a review: edible flowers preservation. Food Rev. Int. 35, 132-154. doi: 10.1080/87559129.2018.1473422

Fossen, T., and Andersen, $\varnothing$ (2003). Anthocyanins from red onion, Allium cepa, withnovel aglycone. Phytochemistry 62, 1217-1220. doi: 10.1016/S00319422(02)00746-X

Friedman, H., Agami, O., Vinokur, Y., Droby, S., Cohen, L., Refaeli, G., et al. (2010). Characterization of yield, sensitivity to Botrytis cinerea and antioxidant content of several rose species suitable for edible flowers. Sci. Hortic. 123, 395-401. doi: 10.1016/j.scienta.2009.09.019

Friedman, H., Vinokur, Y., Rot, I., Rodov, V., Goldman, G., Resnick, N., et al. (2005). Tropaeolum majus L. as edible flowers: growth and postharvest handling. Adv. Hortic. Sci. 19, 3-8. doi: 10.1400/14351

Garzón, G. A., and Wrolstad, R. E. (2009). Major anthocyanins and antioxidant activity of Nasturtium flowers (Tropaeolum majus). Food Chem. 114, 44-49. doi: 10.1016/j.foodchem.2008.09.013

González-Barrio, R., Periago, M. J., Luna-Recio, C., Garcia-Alonso, F. J., and Navarro-González, I. (2018). Chemical composition of the edible flowers, pansy (Viola wittrockiana) and snapdragon (Antirrhinum majus) as new sources of bioactive compounds. Food Chem. 252, 373-380. doi: 10.1016/j.foodchem.2018. 01.102

Gostin, A. I., and Waisundara, V. Y. (2019). Edible flowers as functional food: a review on artichoke (Cynara cardunculus L.). Trends Food Sci. Tech. 86, 381-391. doi: 10.1016/j.tifs.2019.02.015

Granero, A. M., Gonzalez, F. E., Sanz, J. G., and Vidal, J. M. (2005). Analysis of biogenic volatile organic compounds in zucchini flowers: identification of scent sources. J. Chem. Ecol. 31, 2309-2322. doi: 10.1007/s10886-005-7103-2

Grzeszczuk, M., Stefaniak, A., Meller, E., and Wysocka, G. (2018). Mineral composition of some edible flowers. J. Elem. 23, 151-162. doi: 10.5601/jelem. 2017.22.2.1352

Gutowski, M. C., Fix, D. V., Corvalan, J. R., and Johnson, D. A. (1995). Reduction of toxicity of a vinca alkaloid by an anti-vinca alkaloid antibody. Cancer Investig. 13, 370-374. doi: 10.3109/07357909509031917

Haase, H., and Rink, L. (2014). Zinc signals and immune function. Biofactors 40, 27-40. doi: 10.1002/biof.1114

Haviland-Jones, J., Rosario, H. H., Wilson, P., and McGuire, T. R. (2005). An environmental approach to positive emotion: flowers. Evol. Psychol. 3, 104-132. doi: 10.1177/147470490500300109

Hou, W., Pan, Y. Z., and Zhang, Y. (2014). Changes in quality, antioxidant compounds and DPPH radical-scavenging activity of Rosa hybrida flowers during development. New Zeal. J. Crop Hortic. 42, 31-37. doi: 10.1080/ 01140671.2013 .844718

Ishige, K., Schubert, D., and Sagara, Y. (2001). Flavonoids protect neuronal cells from oxidative stress by three distinct mechanisms. Free Radical Bio. Med. 30, 433-446. doi: 10.1016/S0891-5849(00)00498-6

Ito, D., Shinkai, Y., Kato, Y., Kondo, T., and Yoshida, K. (2009). Chemical studies on different color development in blue-and red-colored sepal cells of Hydrangea macrophylla. Biosci. Biotech. Bioch. 73, 1054-1059. doi: 10.1271/bbb.80831

Kaisoon, O., Konczak, I., and Siriamornpun, S. (2012). Potential health enhancing properties of edible flowers from Thailand. Food Res. Int. 46, 563-571. doi: 10.1016/j.foodres.2011.06.016

Kaisoon, O., Siriamornpun, S., Weerapreeyakul, N., and Meeso, N. (2011). Phenolic compounds and antioxidant activities of edible flowers from Thailand. J. Funct. Foods 3, 88-99. doi: 10.1016/j.jff.2011.03.002

Kalemba-Drożdż, M., and Cierniak, A. (2019). Antioxidant and genoprotective properties of extracts from edible flowers. J. Food Nutr. Res. 58, 42-50. doi: 10.13140/RG.2.2.17195.49442/1 
Kast, C., Kilchenmann, V., Reinhard, H., Droz, B., Lucchetti, M. A., Dübecke, A., et al. (2018). Chemical fingerprinting identifies Echium vulgare, Eupatorium cannabinum and Senecio spp. as plant species mainly responsible for pyrrolizidine alkaloids in bee-collected pollen. Food Addit. Contam. A. 35, 316-327. doi: 10.1080/19440049.2017.1378443

Kelley, K. M., Behe, B. K., Biernbaum, J. A., and Poff, K. L. (2001). Consumer preference for edible-flower color, container size, and price. Hortscience 36, 801-804. doi: 10.21273/hortsci.36.4.801

Kelley, K. M., and Biernbaum, J. A. (2000). Organic nutrient management of greenhouse production of edible flowers in containers. Hortscience 35, 453-453. doi: 10.21273/hortsci.35.3.453B

Kelley, K. M., Cameron, A. C., Biernbaum, J. A., and Poff, K. L. (2003). Effect of storage temperature on the quality of edible flowers. Postharvest Biol. Technol. 27, 341-344. doi: 10.1016/S0925-5214(02)00096-0

Khoo, H. E., Azlan, A., Tang, S. T., and Lim, S. M. (2017). Anthocyanidins and anthocyanins: colored pigments as food, pharmaceutical ingredients, and the potential health benefits. Food Nutr. Res. 61:1361779. doi: 10.1080/16546628. 2017.1361779

Kim, G. C., Kim, J. S., Kim, G. M., and Choi, S. Y. (2017). Anti-adipogenic effects of Tropaeolum majus (nasturtium) ethanol extract on 3T3-L1 cells. Food Nutr. Res. 61:1339555. doi: 10.1080/16546628.2017.1339555

Klintschar, M., Beham-Schmidt, C., Radner, H., Henning, G., and Roll, P. (1999). Colchicine poisoning by accidental ingestion of meadow saffron (Colchicum autumnale): pathological and medicolegal aspects. Forensic Sci. Int. 106, 191200. doi: 10.1016/S0379-0738(99)00191-7

Knudsen, J. T., Eriksson, R., Gershenzon, J., and Ståhl, B. (2006). Diversity and distribution of floral scent. The Bot. Rev. 72, 1-120. doi: 10.1663/00068101(2006)72[1:DADOFS]2.0.CO;2

Koch, E., and Malek, F. A. (2011). Standardized extracts from hawthorn leaves and flowers in the treatment of cardiovascular disorders-preclinical and clinical studies. Planta Med. 77, 1123-1128. doi: 10.1055/s-0030-1270849

Koike, A., Barreira, J. C., Barros, L., Santos-Buelga, C., Villavicencio, A. L., and Ferreira, I. C. (2015). Edible flowers of Viola tricolor L. as a new functional food: Antioxidant activity, individual phenolics and effects of gamma and electronbeam irradiation. Food Chem. 179, 6-14. doi: 10.1016/j.foodchem.2015. 01.123

Kou, L., Turner, E. R., and Luo, Y. (2012). Extending the shelf life of edible flowers with controlled release of 1-Methylcyclopropene and modified atmosphere packaging. J. Food Sci. 77, S188-S193. doi: 10.1111/j.1750-3841.2012.02 683.x

Kowalska, J., Pszczoła, K., Wilimowska-Pelc, A., Lorenc-Kubis, I., Zuziak, E., Ługowski, M., et al. (2007). Trypsin inhibitors from the garden four o'clock (Mirabilis jalapa) and spinach (Spinacia oleracea) seeds: isolation, characterization and chemical synthesis. Phytochemistry 68, 1487-1496. doi: 10.1016/j.phytochem.2007.03.012

Krenzelok, E. P. (2010). Aspects of Datura poisoning and treatment. Clin.Toxicol. 48, 104-110. doi: 10.3109/15563651003630672

Kroyer, G., and Hegedus, N. (2001). Evaluation of bioactive properties of pollen extracts as functional dietary food supplement. Innovative ıInnov. Food Sci. Emerg. Technol. 2, 171-174. doi: 10.1016/S1466-8564(01) 00039-X

Ksouri, R., Falleh, H., Megdiche, W., Trabelsi, N., Mhamdi, B., Chaieb, K., et al. (2009). Antioxidant and antimicrobial activities of the edible medicinal halophyte Tamarix gallica L. and related polyphenolic constituents. Food Chem. Toxicol. 47, 2083-2091. doi: 10.1016/j.fct.2009.05.040

Kucekova, Z., Mlcek, J., Humpolicek, P., and Rop, O. (2013). Edible flowersantioxidant activity and impact on cell viability. Cent. Eur. J. Biol. 8, 1023-1031. doi: 10.2478/s11535-013-0212-y

Kwakye, G. F., Jiménez, J., Jiménez, J. A., and Aschner, M. (2018). Atropa belladonna neurotoxicity: implications to neurological disorders. Food Chem. Toxicol. 116, 346-353. doi: 10.1016/j.fct.2018.04.022

Lee, B. H., Nam, T. G., Park, W. J., Kang, H., Heo, H. J., Chung, D. K., et al. (2015). Antioxidative and neuroprotective effects of volatile components in essential oils from Chrysanthemum indicum Linné flowers. Food Sci. Biotechnol. 24, 717-723.

Leonard, A. S., and Masek, P. (2014). Multisensory integration of colors and scents: insights from bees and flowers. J. Comp. Physiol. A 200, 463-474. doi: 10.1007/ s00359-014-0904-4
Li, A. N., Li, S., Li, H. B., Xu, D. P., Xu, X. R., and Chen, F. (2014). Total phenolic contents and antioxidant capacities of 51 edible and wild flowers. J. Funct. Foods 6, 319-330. doi: 10.1016/j.jff.2013.10.022

Llnskens, H. F., and Jorde, W. (1997). Pollen as food and medicine-a review. Econ. Bot. 51, 171-174.

Löffelhardt, W., Kopp, B., and Kubelka, W. (1979). Intracellular distribution of cardiac glycosides in leaves of Convallaria majalis. Phytochemistry 18, 12891291. doi: 10.1016/0031-9422(79)83009-5

Loganayaki, N., Suganya, N., and Manian, S. (2012). Evaluation of edible flowers of agathi (Sesbania grandiflora L. Fabaceae) for in vivo anti-inflammatory and analgesic, and in vitro antioxidant potential. Food Sci. Biotechnol 21, 509-517. doi: 10.1007/s10068-012-0065-6

Loizzo, M. R., Pugliese, A., Bonesi, M., Tenuta, M. C., Menichini, F., Xiao, J., et al. (2016). Edible flowers: a rich source of phytochemicals with antioxidant and hypoglycemic properties. J. Agric. Food Chem. 64, 2467-2474. doi: 10.1021/acs. jafc.5b03092

Lu, B., Li, M., and Yin, R. (2016). Phytochemical content, health benefits, and toxicology of common edible flowers: a review (2000-2015). Crit. Rev. Food Sci. 56, S130-S148. doi: 10.1080/10408398.2015.1078276

Lucchetti, M. A., Glauser, G., Kilchenmann, V., Dübecke, A., Beckh, G., Praz, C., et al. (2016). Pyrrolizidine alkaloids from Echium vulgare in honey originate primarily from floral nectar. J. Agric. Food Chem. 64, 5267-5273. doi: 10.1021/ acs.jafc.6b02320

Ma, D., and Wako, Y. (2017). Evaluation of phenolic compounds and neurotrophic/neuroprotective activity of cultivar extracts derived from Chrysanthemum morifolium flowers. Food Sci. Technol. Res. 23, 457-467. doi: $10.3136 /$ fstr.23.457

Matyjaszczyk, E., and Śmiechowska, M. (2019). Edible flowers, benefits and risks pertaining to their consumption. Trends Food Sci. Tech. 91, 670-674.

Melillo, L. (1994). Diuretic plants in the paintings of Pompeii. Am. J. Nephrol. 14, 423-425. doi: 10.1159/000168758

Melnyk, J. P., Wang, S., and Marcone, M. F. (2010). Chemical and biological properties of the world's most expensive spice: Saffron. Food Res. Int. 43, 1981-1989. doi: 10.1016/j.foodres.2010.07.033

Mikołajczak, N., Sobiechowska, D. A., and Tańska, M. (2020). Edible flowers as a new source of natural antioxidants for oxidative protection of cold-pressed oils rich in omega-3 fatty acids. Food Res. Int. 134, 109216. doi: 10.1016/j.foodres. 2020.109216

Mithöfer, A., and Boland, W. (2012). Plant defense against herbivores: chemical aspects. Annu. Rev. Plant Biol. 63, 431-450. doi: 10.1146/annurev-arplant042110-103854

Mlcek, J., and Rop, O. (2011). Fresh edible flowers of ornamental plants-A new source of nutraceutical foods. Trends Food Sci. Tech. 22, 561-569. doi: 10.1016/ j.tifs.2011.04.006

Mohamed, M. A., Hamed, M. M., Abdou, A. M., Ahmed, W. S., and Saad, A. M. (2011). Antioxidant and cytotoxic constituents from Wisteria sinensis. Molecules 16, 4020-4030. doi: 10.3390/molecules 16054020

Morton, J. F., Alvarez, E., and Quiñonez, C. (1990). Loroco. Fernaldia pandurata (Apocynaceae): a popular edible flower of Central America. Econ. Bot. 44, 301-310. doi: 10.1007/BF03183911

Mulík, S., and Ozuna, C. (2020). Mexican edible flowers: cultural background, traditional culinary uses, and potential health benefits. Int. J. Gastron. Food Sci 21:100235. doi: 10.1016/j.ijgfs.2020.100235

Mustonen, S., and Tuorila, H. (2010). Sensory education decreases food neophobia score and encourages trying unfamiliar foods in 8-12-year-old children. Food Qual. Prefer. 21, 353-360. doi: 10.1016/j.foodqual.2009.09.001

Navarro-González, I., González-Barrio, R., García-Valverde, V., Bautista-Ortín, A. B., and Periago, M. J. (2015). Nutritional composition and antioxidant capacity in edible flowers: Characterisation of phenolic compounds by HPLCDAD-ESI/MSn. Int. J. Mol. 16, 805-822. doi: 10.3390/ijms16010805

Nicolau, A. I., and Gostin, A. I. (2015). Safety of Edible Flowers. Regulating Safety of Traditional and Ethnic Foods. Waltham MA: Academic Press, 395-419. doi: 10.1016/B978-0-12-800605-4.00021-9

Nicolson, W., Nepi, M., and Pacini, E. (2007). Nectaries and Nectar. Dordrecht: Springer, 215-264. doi: 10.1007/978-1-4020-5937-7_5

Niizu, P. Y., and Rodriguez-Amaya, D. B. (2005). Flowers and leaves of Tropaeolum majus L. as rich sources of lutein. J. Food Sci. 70, S605-S609. doi: 10.1111/j.13652621.2005.tb08336.x 
Nwachukwu, I. D., Udenigwe, C. C., and Aluko, R. E. (2016). Lutein and zeaxanthin: Production technology, bioavailability, mechanisms of action, visual function, and health claim status. Trends Food Sci. Tech. 49, 74-84.

Pacini, E., Nepi, M., and Vesprini, J. L. (2003). Nectar biodiversity: a short review. Plant Sys. Evol. 238, 7-21. doi: 10.1007/s00606-002-0277-y

Park, Y. J., Park, S. Y., Valan Arasu, M., Al-Dhabi, N. A., Ahn, H. G., Kim, J. K., et al. (2017). Accumulation of carotenoids and metabolic profiling in different cultivars of Tagetes flowers. Molecules 22:313. doi: 10.3390/molecules22020313

Pichersky, E., and Gershenzon, J. (2002). The formation and function of plant volatiles: perfumes for pollinator attraction and defense. Curr. Opin. Plant Biol. 5, 237-243. doi: 10.1016/S1369-5266(02)00251-0

Pires, T. C., Barros, L., Santos-Buelga, C., and Ferreira, I. C. (2019). Edible flowers: Emerging components in the diet. Trends Food Sci. Tech. 93, 244-258. doi: 10.1016/j.tifs.2019.09.020

Pires, T. C., Dias, M. I., Barros, L., Calhelha, R. C., Alves, M. J., Oliveira, M. B., et al. (2018). Edible flowers as sources of phenolic compounds with bioactive potential. Food Res. Int. 105, 580-588. doi: 10.1016/j.foodres.2017.11.014

Pliner, P., and Hobden, K. (1992). Development of a scale to measure the trait of food neophobia in humans. Appetite 19, 105-120. doi: 10.1016/0195-6663(92) 90014-W

Popescu, R., and Kopp, B. (2013). The genus Rhododendron: an ethnopharmacological and toxicological review. J. Ethnopharmacol. 147, 42-62. doi: 10.1016/j.jep.2013.02.022

Pusey, P. L., Rudell, D. R., Curry, E. A., and Mattheis, J. P. (2008). Characterization of stigma exudates in aqueous extracts from apple and pear flowers. Hortsci. 43, 1471-1478. doi: 10.21273/hortsci.43.5.1471

Rachkeeree, A., Kantadoung, K., Suksathan, R., Puangpradab, R., Page, P. A., and Sommano, S. R. (2018). Nutritional compositions and phytochemical properties of the edible flowers from selected zingiberaceae found in Thailand. Front. Nutr. 5:3. doi: $10.3389 /$ fnut. 2018.00003

Ranfa, A., and Bodesmo, M. (2017). An Ethnobotanical investigation of traditional knowledge and uses of edible wild plants in the Umbria Region. Central Italy. J. Appl. Bot. Food Qual. 90, 246-258.

Ratnasooriya, W. D., Pieris, K. P. P., Samaratunga, U., and Jayakody, J. R. A. C. (2004). Diuretic activity of Spilanthes acmella flowers in rats. J. Ethnopharmacol. 91, 317-320. doi: 10.1016/j.jep.2004.01.006

Rezende, F., Sande, D., Coelho, A. C., Oliveira, G., Boaventura, M. A., and Takahashi, J. A. (2019). Edible flowers as innovative ingredients for future food development: anti-alzheimer, antimicrobial, and antioxidant potential. Chem. Eng. Trans. 75, 337-342.

Roberts, M. (2000). Edible \& Medicinal Flowers. Claremont: New Africa Books.

Rodrigues, H., Cielo, D. P., Goméz-Corona, C., Silveira, A. A. S., Marchesan, T. A., Galmarini, M. V., et al. (2017). Eating flowers? Exploring attitudes and consumers' representation of edible flowers. Food Res. Int. 100, 227-234. doi: 10.1016/j.foodres.2017.08.018

Rollin, O., Benelli, G., Benvenuti, S., Decourtye, A., Wratten, S. D., Canale, A., et al. (2016). Weed-insect pollinator networks as bio-indicators of ecological sustainability in agriculture. A review. Agron. Sustain. Dev. 36, 1-22. doi: 10. 1007/s13593-015-0342-x

Rop, O., Mlcek, J., Jurikova, T., Neugebauerova, J., and Vabkova, J. (2012). Edible flowers-a new promising source of mineral elements in human nutrition. Molecules 17, 6672-6683. doi: 10.3390/molecules 17066672

Ryu, S. Y., Choi, S. U., Lee, C. O., Lee, S. H., Ahn, J. W., and Zee, O. P. (1994). Antitumor activity of some phenolic components in plants. Arch. Pharm. Res. 17, 42-44. doi: 10.1007/BF02978247

Sadati Lamardi, S. N., Taleb Kashefi, N., and Yassa, N. (2018). Phytochemical Evaluation, Antioxidant Activity and Toxicity of Paeonia daurica ssp. macrophylla root. Res. J. Pharmacogn. 5, 9-15. doi: 10.22127/RJP.2018. 58475

Safder, M., Imran, M., Mehmood, R., Malik, A., Afza, N., Iqbal, L., et al. (2009). Asphorodin, a potent lipoxygenase inhibitory triterpene diglycoside from Asphodelus tenuifolius. J. Asian Nat. Prod. Res. 11, 945-950. doi: 10.1080/ 10286020903214197

Sagoo, S. K., Little, C. L., and Mitchell, R. T. (2001). The microbiological examination of ready-to-eat organic vegetables from retail establishments in the United Kingdom. Lett. Appl. Microbiol. 33, 434-439. doi: 10.1046/j.1472-765X. 2001.01026.x

Schep, L. J., Slaughter, R. J., and Beasley, D. M. G. (2009). Nicotinic plant poisoning. Clin. Toxicol. 47, 771-781. doi: 10.1080/15563650903252186
Schulp, C. J., Thuiller, W., and Verburg, P. H. (2014). Wild food in Europe: a synthesis of knowledge and data of terrestrial wild food as an ecosystem service. Ecol. Econom. 105, 292-305. doi: 10.1016/j.ecolecon.2014.06.018

Shams, T. A., Gosselin, S., and Chuang, R. (2017). Unintentional ingestion of black henbane: two case reports. Toxicol. Commun. 1, 37-40. doi: 10.1080/24734306. 2017.1408876

Shanahan, M., So, S., Compton, S. G., and Corlett, R. (2001). Fig-eating by vertebrate frugivores: a global review. Biol. Rev. 76, 529-572. doi: 10.1017/ S1464793101005760

Sharma, M., and Reynnells, R. (2018). Importance of soil amendments: survival of bacterial pathogens in manure and compost used as organic fertilizers. Preharv. Food Saf 4, 159-175. doi: 10.1128/9781555819644.ch9

Singh, O., Khanam, Z., Misra, N., and Srivastava, M. K. (2011). Chamomile (Matricaria chamomilla L.): an overview. Pharmacogn. Rev. 5, 82-95. doi: 10. 4103/0973-7847.79103

Šivel, M., Kráčmar, S., Fišera, M., Klejdus, B., and Kubáň, V. (2014). Lutein content in marigold flower (Tagetes erecta L.) concentrates used for production of food supplements. Czech J. Food Sci. 32, 521-525. doi: 10.17221/104/2014-cjfs

Slenter, I. J., Djajadiningrat-Laanen, S. C., De Vries, I., and Dijkman, M. A. (2019). Intoxication with Ornithogalum arabicum is a potential cause of visual impairment and irreversible blindness in dogs. Toxicon: $X$ 4:100014. doi: 10. 1016/j.toxcx.2019.100014

Smith-Kielland, I., Dornish, J. M., Malterud, K. E., Hvistendahl, G., Rømming, C., Bøckmann, O. C., et al. (1996). Cytotoxic triterpenoids from the leaves of Euphorbia pulcherrima. Planta Med. 62, 322-325. doi: 10.1055/s-2006-957893

Sotelo, A., López-García, S., and Basurto-Peña, F. (2007). Content of nutrient and antinutrient in edible flowers of wild plants in Mexico. Plant Foods Hum. Nutr. 62, 133-138. doi: 10.1007/s11130-007-0053-9

Specht, K., Siebert, R., Hartmann, I., Freisinger, U. B., Sawicka, M., Werner, A., et al. (2014). Urban agriculture of the future: an overview of sustainability aspects of food production in and on buildings. Agr. Hum. Values 31, 33-51. doi: 10.1007/s10460-013-9448-4

Spoerke, D. G., Spoerke, S. E., Hall, A., and Rumack, B. H. (1987). Toxicity of Cyclamen persium (Mill). Vet. Hum. Toxicol. 29, 250-251.

Sugawara, T., and Igarashi, K. (2009). Identification of major flavonoids in petals of edible chrysanthemum flowers and their suppressive effect on carbon tetrachloride-induced liver injury in mice. Food Sci. Technol. Res. 15, 499-506. doi: 10.3136/fstr.15.499

Tamilselvan, N., Thirumalai, T., Shyamala, P., and David, E. (2014). A review on some poisonous plants and their medicinal values. J. Acute Dis 3, 85-89. doi: 10.1016/S2221-6189(14)60022-6

Turner, N. J. (1984). Counter-irritant and other medicinal uses of plants in Ranunculaceae by native peoples in British Columbia and neighbouring areas. J. Ethnopharmacol. 11, 181-201. doi: 10.1016/0378-8741(84)90038-2

Ukiya, M., Akihisa, T., Tokuda, H., Suzuki, H., Mukainaka, T., Ichiishi, E., et al. (2002). Constituents of Compositae plants: III. Anti-tumor promoting effects and cytotoxic activity against human cancer cell lines of triterpene diols and triols from edible chrysanthemum flowers. Cancer Lett. 177, 7-12. doi: 10.1016/ S0304-3835(01)00769

Ukiya, M., Akihisa, T., Yasukawa, K., Kasahara, Y., Kimura, Y., Koike, K., et al. (2001). Constituents of compositae plants. 2. Triterpene diols, triols, and their 3-O-fatty acid esters from edible chrysanthemum flower extract and their anti-inflammatory effects. J. Agric. Food Chem. 49, 3187-3197. doi: 10.1021/ jf010164e

Van Bruggen, A. H., Gamliel, A., and Finckh, M. R. (2016). Plant disease management in organic farming systems. Pest Manag. Sci. 72, 30-44. doi: 10. 1002/ps. 4145

Vanbergen, A. J., and Initiative, T. I. P. (2013). Threats to an ecosystem service: pressures on pollinators. Front. Ecol. Environ. 11:251-259. doi: 10.1890/120126

Vetter, J. (2004). Poison hemlock (Conium maculatum L.). Food Chem. Toxicol. 42, 1373-1382. doi: 10.1016/j.fct.2004.04.009

Villavicencio, A. L., Heleno, S. A., Calhelha, R. C., Santos-Buelga, C., Barros, L., and Ferreira, I. C. (2018). The influence of electron beam radiation in the nutritional value, chemical composition and bioactivities of edible flowers of Bauhinia variegata L. var. candida alba Buch.-Ham from Brazil. Food Chem. 241, 163-170. doi: 10.1016/j.foodchem.2017.08.093

Voon, H. C., Bhat, R., and Rusul, G. (2012). Flower extracts and their essential oils as potential antimicrobial agents for food uses and pharmaceutical applications. Compr. Rev. Food Sci. F. 11, 34-55. doi: 10.1111/j.1541-4337.2011.00169.x 
Wetzel, K., Lee, J., Lee, C. S., and Binkley, M. (2010). Comparison of microbial diversity of edible flowers and basil grown with organic versus conventional methods. Can. J. Microbiol. 56, 943-951. doi: 10.1139/W10-082

Wink, M., Hartmann, T., Witte, L., and Rheinheimer, J. (1982). Interrelationship between quinolizidine alkaloid producing legumes and infesting insects: exploitation of the alkaloid-containing phloem sap of Cytisus scoparius by the broom aphid Aphis cytisorum. Z. Naturforsch. 37, 1081-1086. doi: 10.1515/znc1982-11-1206

Wongwattanasathien, O., Kangsadalampai, K., and Tongyonk, L. (2010). Antimutagenicity of some flowers grown in Thailand. Food Chem. Toxicol. 48, 1045-1051. doi: 10.1016/j.fct.2010.01.018

Xiong, L., Yang, J., Jiang, Y., Lu, B., Hu, Y., Zhou, F., et al. (2014). Phenolic compounds and antioxidant capacities of 10 common edible flowers from China. J. Food Sci. 79, C517-C525. doi: 10.1111/1750-3841.12404

Yang, E. H., Shah, S., and Criley, J. M. (2012). Digitalis toxicity: a fading but crucial complication to recognize. Am. J. Med. 125, 337-343. doi: 10.1016/j.amjmed. 2011.09.019

Zeng, Y., Deng, M., Lv, Z., and Peng, Y. (2014). Evaluation of antioxidant activities of extracts from 19 Chinese edible flowers. SpringerPlus 3, 1-5. doi: 10.1186/ 2193-1801-3-315
Zhao, L., Fan, H., Zhang, M., Chitrakar, B., Bhandari, B., and Wang, B. (2019) Edible flowers: Review of flower processing and extraction of bioactive compounds by novel technologies. Food Res. Int. 126:108660. doi: 10.1016/j. foodres.2019.108660

Zheng, J., Yu, X., Maninder, M., and Xu, B. (2018). Total phenolics and antioxidants profiles of commonly consumed edible flowers in China. Int. J. Food Prop. 21, 1524-1540. doi: 10.1080/10942912.2018.149 4195

Conflict of Interest: The authors declare that the research was conducted in the absence of any commercial or financial relationships that could be construed as a potential conflict of interest.

Copyright (๑) 2021 Benvenuti and Mazzoncini. This is an open-access article distributed under the terms of the Creative Commons Attribution License (CC BY). The use, distribution or reproduction in other forums is permitted, provided the original author(s) and the copyright owner(s) are credited and that the original publication in this journal is cited, in accordance with accepted academic practice. No use, distribution or reproduction is permitted which does not comply with these terms. 